\section{Income and out-of-pocket health expenditure in living arrangements of families with older adults in Brazil}

\author{
Renda e gastos diretos em saúde de acordo \\ com diferentes arranjos de moradia em \\ famílias com idosos no Brasil
}

Ingresos y gastos personales en salud dentro de hogares familiares conviviendo con ancianos en Brasil

\begin{abstract}
The main objective of this study was to characterize household sociodemographic and economic patterns of different living arrangements of families with older adults in Brazil and their relationship with income and outof-pocket health expenditure. Data were extracted from the 2008-2009 Brazilian Household Budget Survey (POF in Portuguese) database of the Brazilian Institute of Geography and Statistics. Families with older adults represented 28\% of all families, being smaller and having higher average income when compared to families without older adults. Older adults were head of the household in 85\% of the families, with income based mainly on social protection policies. The families with older adult or couple as head of the household had significantly higher average monthly income. The proportion of out-of-pocket health expenditure per income quintile per capita was higher for families with one older adult or couple as head of the household, when compared to families without older adult as head of the household and even more in families without older adults at all. These findings allow the identification of potential positive impacts on the quality of life of families with older adults in Brazil. The higher household income of families with older adults is a consequence of the expansion of inclusive social protection policies for this population in the 2000s in Brazil, especially for families with lower average income levels, representing 4/5 of this population. The economic and political crisis in the 2010s have probably reduced these families' relative advantage, and this study will compare with results of the next survey.
\end{abstract}

Aged; Family; Income; Health Expenditures; Social Security

\author{
Christine Grutzmann Faustino 1,2 \\ Renata Bertazzi Levy 3 \\ Daniela Silva Canella 4 \\ César de Oliveira 5 \\ Hillegonda Maria Dutilh Novaes 3
}

\author{
Correspondence \\ C. G. Faustino \\ Av. Mato Grosso 5185, Campo Grande, MS 79031-000, Brasil. \\ christinefaustino@yahoo.com.br \\ 1 Universidade Estadual do Mato Grosso do Sul, Campo \\ Grande, Brasil. \\ 2 Universidade Católica Dom Bosco, Campo Grande, Brasil. \\ 3 Faculdade de Medicina, Universidade de São Paulo, São Paulo, \\ Brasil. \\ 4 Instituto de Nutrição, Universidade do Estado do Rio de \\ Janeiro, Rio de Janeiro, Brasil. \\ 5 University College London, London, U.K.
}




\section{Introduction}

Population aging is a global phenomenon. Rapid demographic change due to reduced fertility and infant mortality rates has increased life expectancy. The proportion of individuals aged 60 and older has increased from $8 \%$ in 1950 to $11 \%$ in 2010 and is expected to reach $21.5 \%$ (> 2 billion) in 2050, with $80 \%$ living in middle and low income countries 1 . In 1950, in Brazil, $4.9 \%$ of the population were aged 60 and older; in 2010 this proportion increased to $10.7 \%$ and it is expected to reach $32.2 \%$ in 2060 2. The demographic transition has had an impact on population health, with an increase in noncommunicable diseases and disability, particularly in later life 3 . Older adults are a vulnerable group and have been the object of specific public policies in many countries, dedicated to preserve their income, health, and quality of life.

In Brazil, three social policies address these challenges: income policy (social security), social care, and health policies 4 . The policies regarding income protection for older adults are part of social protection policies and were expanded in the 2000s to include older adults with low income in government programs, such as the non-contributory pension program (BPC in Portuguese), paying a minimum wage to older adults who fulfil the social vulnerability criteria. Additionally, the family still is a source of informal support for the older population, and in many cases the only source 4 .

Households can be very diverse and different types have been identified in the literature and described regarding their living arrangements, considering demographic composition, income, person of reference, access to health resources, and health status, among others 5,6 . The concept of reference family member implies that this person has authority and responsibility and is, mostly, the financial head of the family ${ }^{7}$. An older adult may have different roles within the household, varying from very dependent to head of the household. Their role influences how household income is allocated 8 .

The older adult's presence has been associated with an increase or decrease in the average per capita family income, but the conditions associated with aging are expected to impact the household budget due to the treatment of aging related health conditions i.e. the presence of multiple non-communicable chronic diseases 6,9. Out-of-pocket expenditure in families is considered a useful indicator for health needs, but difficult to interpret. It may be low (in absolute or relative values), when there are no health needs or when health needs are present, but the income does not cover other essential needs; or high, indicating the decision to provide care to acute needs, when there is a lack of access to public health care system or the care provided does not fulfil expectations 10,11.

Family structures are complex and dynamic systems with inter-relationships between its members that affect health, social care, and financial decisions and are dependent on cultural contexts 12 . The usual approach comprises analyses based on individual older adults, even when they include family arrangements as a variable, do not capture the impact of the older adult's presence and characteristics on family arrangements and living conditions in a population perspective. There is limited research on living arrangements of households with older adults, their financial characteristics, and health expenditures to contribute to a better understanding of the older population's social and economic conditions, as well as their families'. Income is associated with social empowerment and the potential for health care expenditure for themselves and/or other family members 13 .

In Brazil, national surveys are conducted by the Brazilian Institute of Geography and Statistics (IBGE) on a regular basis, covering a wide range of topics. The Brazilian Household Budget Survey (POF in Portuguese) is a household survey whose main objective is to gather information on household expenditure structure (products, services, and assets), nutritional status, and living conditions of Brazilian families. It is a nationally representative survey and measures assets, expenditures, and variations on families' assets 7 .

Studies of POF editions on health expenditures have not considered the impact of demographic and economic characteristics of families with older adults, the types of family arrangements, and the presence of social policies in their analyses. The existing literature considers all families and differentiates them mainly regarding social strata when analyzing the trends in magnitude and in health expenditures distribution, as well as the historical trends $14,15,16$.

When comparing the 1987 and 1996 POF editions, the weight of health care spending in the household budget of the selected lower and middle strata grew by 50\% 14. In 1996, the relative weight 
of drug spending was higher, and the weight of health care expenses increased in the upper stratum. However, at the same time there was a reduction of the absolute expenditures value 14.

Data from the POF 1995-1996 showed health spending accounted for $9 \%$ of family consumption expenditure in that period, being the fourth largest group of household expenditures, following housing, food, and transportation expenses 15 .

The trend of family health spending was assessed in the three prior editions to the POF 2008-2009 16. While in 1987-1988 health accounted for 5.3\% of total household expenditures, this percentage increased in 1995-1996 to 6.5\%, but fell again in 2002-2003 to 5.1\%. The increase in sharing health spending occurred between 1987-1988 and between 1995-1996, with a subsequent drop between 2002-2003, which occurred in all tenths of income. Between the first and second POF, the share of health spending increased more in poorer families than in richer. The decrease in the relative share of health expenditures within total household spending, observed in the POF 2002-2003, has been attributed to greater coverage by the Brazilian Unified National Health System (SUS in Portuguese), mainly among the poorest segments of the population 16 .

Access to public health services has increased over the last three decades and indicators, such as the percentage of people who report having visited a doctor and dentist, show that more people have been searching for and obtaining health services as a consequence of the expansion of services, programs, and professionals associated with SUS 17.

The first POF is from 1987-1988 and the last one is from 2008-2009. The next survey started in 2017 and ended in 2018 18. Data from the last wave are ten years old but are still important because 2008 represents a decade of expansion in social policies and pension coverage in Brazil, particularly for poor and older people. These policies are being reviewed by the government, and it is important to study this period to have comparative data when new survey results are shown after severe national economic crisis and changes in governmental social priorities 19.

The objective of this study is to analyze household sociodemographic and financial characteristics of families with older adults in different living arrangements and their relation to monthly health expenditure, using the POF 2008-2009 data conducted by IBGE.

\section{Methods}

\section{Sample and data collection}

The study used the POF data of IBGE. This was a population-based study involving 55,970 Brazilian households (i.e. 56,091 families), based on a complex sample plan using two-stage cluster sampling, with random selection of census sectors and households during the first and the second stage, respectively ${ }^{7}$.

The POF 2008-2009 has seven questionnaires measuring the residents' characteristics, household and families, information on income and individual and collective expenditures, subjective assessment of living conditions, and individual food consumption. Data were collected directly in the selected households for nine consecutive days. Household is defined as a separate and independent place, which is inhabited by one or more individuals and may contain one or more families. A family (i.e. the consumption unit) was chosen as the analytic unit in this study. A family is a unit composed by one resident or a group of residents who use the same food source and/or collective food acquisitions 20 .

\section{Demographic and socioeconomic variables}

A participant was classified as an older adult when aged 60 and older. Head of the household was a resident indicated by family member, who had to satisfy at least one out of the following conditions: (i) to be responsible for paying rent; (ii) to be responsible for paying the mortgage monthly instalments; and (iii) to be responsible for paying other housing-related expenditures (condominium, council tax, services charges, etc.). In cases when there was no one who satisfied the above criteria, residents indicated a person they considered as the reference family member 20 . 
Families with older adults were divided into three types of living arrangements. The first was composed by families with one older adult who was head of the household. The second arrangement was composed by families with two older adults and one of them was head of the household. In $91 \%$ of these families the second older adult was a partner and this type of family was called "families with an older couple". Finally, the third type of family was composed by families with an older adult who was not head of the household, families with more than one head of the household, and/or families with more than three older adults. Importantly, this type of family arrangement was mainly composed by families with only one older adult (86\%).

The sociodemographic and economic variables included in the analysis were: age group ( $\geq 60$ $<70 ; \geq 70<80 ; \geq 80$ ), gender, ethnicity (white; brown; black; other), years in school $(\leq 4 ;>4 \leq 8,>8$ $\leq 11$; $>11$ ), monetary gains in the past 12 months (yes; no; non-response), type of monetary gain (social security/social benefit; employment/patrimony; family financial support; other), and having a private health insurance (yes; no). These variables were stratified by geographic region (North; Northeast; Central; Southeast; South). Other variables were also analyzed: mean number of residents, presence of children aged 5 or younger (yes; no), monthly income per capita (continuous and quintile), monetary health expenditure in the past three months (yes; no), monthly health expenditure per capita, and proportion of health expenditure per capita per quintile of monthly income per capita. The variables were stratified by the presence of older adults within the household and then the families with older adults were stratified regarding the three family living arrangements.

The types of monetary gain were grouped regarding the classification of benefits recommended by the General Scheme of Social Security of the Brazilian Ministry of Social Security and the list of social programs of the Brazilian Ministry of Social Development and Ministry of Employment and Social Programs 21,22.

Health expenditures were defined as monetary expenditures on health and medicines by and for the family itself. The reference period for general health expenditures was 90 days and for medicines expenditures was 30 days. General health expenditures were converted to monthly expenditures. The health expenditures impact on income was estimated in proportion terms of monthly health expenditure per capita per monthly income per capita. Income and expenditure values in Brazilian Reais (BRL) were converted to U.S. Dollar (USD) based on the purchasing power parity (PPP 2009: USD $1.00=$ BRL 1.294) 23,24 .

\section{$\underline{\text { Statistical analysis }}$}

Descriptive analysis of individual older Brazilian adults' characteristics stratified by geographic region, family arrangements characteristics (regarding the older adult's presence), and the different family arrangements in families with an older adult were shown with frequency distributions and 95\% confidence intervals (95\%CI). All analysis were weighted to account for survey sampling and sample weights, representing the Brazilian population.

All analysis were performed using the Stata version 11 (https://www.stata.com). The confidence intervals were set at $95 \%$.

\section{Ethical approval}

This study was approved by the Ethics Committee of the Faculty of Medicine of the University of São Paulo (process n. 756.513). The dataset used in this study is publicly available. All the information used in this study regarding the participants and their families is confidential. 


\section{Results}

\section{Individual characteristics}

The sample comprised of 190,159 individuals with 20,114 older adults (11\%). Table 1 displays the Brazilian older adults' distribution by geographical regions. Most participants lived in the Southeast (46\%), and the region with the fewest participants was the North (5\%). There were significantly less older men than older women in the Northeast, Southeast, and South regions.

In all regions, a high proportion of older adults had less than four years in school, with the highest in the Northeast (81\%) and the lowest in the Southeast (66\%). Older adults have sociodemographic characteristics similar to the regional population in general when distributed by geographical regions. These findings highlight differences in sociodemographic composition and access to education and health care among the Brazilian regions 25. Historic, economic, and social differences contribute to sustain the existing demographic, social, and economic regional inequalities in Brazil: North and Northeast always present a more unfavorable situation than Southeast and South 26.

The proportion of older adults who were head of the household was similar in all five regions. Most Brazilian older adults (85-91\%) reported a monetary gain in the past 12 months with regional variations, and the most frequent sources were social security/social programs. Around one third of the participants had health insurance with important differences between regions. Brazil has a public national health care system with free access to the population, but it struggles with lack of resources. Having a health insurance is expected to protect people from difficulties in access to specialized health care 27 .

\section{Family characteristics}

The sample comprised 56,091 families. Nearly $28 \%$ of them had older adults in their living arrangements. Table 2 shows the families' distribution regarding older adults. In families with older adults, $55 \%$ had one older adult as head of the household and 30\% had an older couple in the household, with one of them being head of the household.

Table 3 presents the families' distribution regarding older adults by social and demographic characteristics, monthly income per capita per area of residence, region quintile and monthly health expenditure per capita, and proportion of monthly health expenditure per capita to monthly income per capita quintile. Families without an older adult usually had more residents. The number of children aged 5 and younger in these families was 3.2 times higher when compared to families with older adults. Area of residence and geographic region distribution were similar in both groups.

The average monthly income per capita for families with older adults was nearly $1 / 4$ higher than in families without older adults. The monthly income per capita in urban areas was significantly higher than in rural areas in both types of families, and the income of those with older adults was higher. The monthly income per capita for the Central, Southeast, and South was significantly higher than in the North and Northeast regions for both types of families. The income reported by families with older adults was higher in all regions, however these differences were not statistically significant in the North and South. Families with older adults reported more frequently income from social security/social benefit. Families without older adults reported a higher frequency of monetary gains from employment/patrimony and family financial support.

The distribution of average income quintile per capita showed similar values in families with and without older adults except for the highest income quintile, with a higher income in families with older adults. The income distribution in quintile is biased: the $20 \%$ with highest income per capita have a 20 times higher income than the $20 \%$ with the lowest income.

Most families, with (87\%) and without (82\%) older adults, had health expenditure in the last three months, but the per capita average expenditure was 2.4 times higher in families with older adults. The proportion of monthly health expenditure per capita per monthly income per capita was higher in families with older adults in all but the lowest income quintile.

Table 4 shows the different living arrangements distribution with older adults by demographic and economic characteristics, monthly income per capita per area of residence, region and quintile, 


\section{Table 1}

Older Brazilian adults' sociodemographic and economic characteristics by geographic region. Brazilian Household Budget Survey, 2008-2009.

\begin{tabular}{|c|c|c|c|c|c|c|}
\hline Characteristics & $\begin{array}{c}\text { North } \\
\%(95 \% \mathrm{Cl})\end{array}$ & $\begin{array}{l}\text { Northeast } \\
\%(95 \% \mathrm{Cl})\end{array}$ & $\begin{array}{c}\text { Central } \\
\%(95 \% \mathrm{Cl})\end{array}$ & $\begin{array}{l}\text { Southeast } \\
\%(95 \% \mathrm{Cl})\end{array}$ & $\begin{array}{c}\text { South } \\
\%(95 \% \mathrm{Cl})\end{array}$ & $\begin{array}{c}\text { Brazil } \\
\%(95 \% \mathrm{Cl})\end{array}$ \\
\hline Region of residence & $5.09(4.72 ; 5.45)$ & $26.68(25.65 ; 27.71)$ & $6.27(5.91 ; 6.64)$ & $46.09(44.66 ; 47.53)$ & $15.87(15.05 ; 16.69)$ & - \\
\hline \multicolumn{7}{|l|}{ Age group (years) } \\
\hline$\geq 60<70$ & $59.40(56.42 ; 62.37)$ & $55.20(53.77 ; 56.63)$ & $59.19(56.53 ; 61.84)$ & $55.84(53.47 ; 58.21)$ & $55.90(53.39 ; 58.42)$ & $56.07(54.82 ; 57.32)$ \\
\hline$\geq 70<80$ & $29.05(26.29 ; 31.81)$ & $29.18(27.81 ; 30.56)$ & $30.16(27.79 ; 32.54)$ & $31.64(29.72 ; 33.56)$ & $31.72(29.44 ; 34.00)$ & $30.77(29.73 ; 31.82)$ \\
\hline$\geq 80$ & $11.55(9.78 ; 13.32)$ & $15.61(14.49 ; 16.74)$ & $10.65(9.19 ; 12.12)$ & $12.52(11.00 ; 14.04)$ & $12.37(10.36 ; 14.39)$ & $13.16(12.32 ; 13.99)$ \\
\hline \multicolumn{7}{|l|}{ Gender } \\
\hline Male & $50.20(47.86 ; 52.55)$ & $43.82(42.69 ; 44.96)$ & $48.56(46.58 ; 50.54)$ & $43.75(42.20 ; 45.31)$ & $44.00(42.21 ; 45.78)$ & $44.44(43.59 ; 45.29)$ \\
\hline Female & $49.80(47.45 ; 52.14)$ & $56.18(55.04 ; 57.31)$ & $51.44(49.46 ; 53.42)$ & $56.25(54.69 ; 57.80)$ & $56.00(54.22 ; 57.79)$ & $55.56(54.71 ; 56.41)$ \\
\hline \multicolumn{7}{|l|}{ Race } \\
\hline White & $23.27(20.58 ; 25.96)$ & $30.83(29.15 ; 32.50)$ & $47.76(45.03 ; 50.49)$ & $64.34(61.89 ; 66.80)$ & $82.25(80.20 ; 84.30)$ & $55.11(53.71 ; 56.52)$ \\
\hline Brown & $66.82(63.88 ; 69.77)$ & $58.63(56.95 ; 60.30)$ & $41.94(39.28 ; 44.60)$ & $25.04(22.97 ; 27.10)$ & $13.26(11.49 ; 15.04)$ & $35.32(34.08 ; 36.56)$ \\
\hline Black & $6.92(5.48 ; 8.36)$ & $9.57(8.53 ; 10.61)$ & $8.93(7.43 ; 10.42)$ & $8.31(7.11 ; 9.51)$ & $2.89(2.17 ; 3.62)$ & $7.75(7.11 ; 8.40)$ \\
\hline Other * & $2.99(2.08 ; 3.89)$ & $0.98(0.66 ; 1.29)$ & $1.37(0.77 ; 1.97)$ & $2.31(1.46 ; 3.17)$ & $1.59(0.94 ; 2.25)$ & $1.82(1.40 ; 2.24)$ \\
\hline \multicolumn{7}{|l|}{ Years in school } \\
\hline$\leq 4$ & 76.35 (73.66; 79.04) & $80.93(79.46 ; 82.40)$ & $69.55(66.92 ; 72.19)$ & $65.95(63.27 ; 68.63)$ & $66.87(63.97 ; 69.77)$ & $70.85(69.42 ; 72.27)$ \\
\hline$>4 \leq 8$ & $11.94(9.94 ; 13.94)$ & $8.30(7.44 ; 9.16)$ & $12.95(11.22 ; 14.67)$ & $13.14(11.66 ; 14.61)$ & $19.05(17.00 ; 21.11)$ & $12.71(11.90 ; 13.52)$ \\
\hline$>8$ & $11.21(9.03 ; 13.38)$ & $10.37(9.16 ; 11.58)$ & $17.37(15.11 ; 19.64)$ & $20.70(18.19 ; 23.21)$ & $13.64(11.39 ; 15.89)$ & $16.13(14.84 ; 17.43)$ \\
\hline Unknown & $0.50(0.06 ; 0.94)$ & $0.40(0.23 ; 0.58)$ & $0.13(0.01 ; 0.25)$ & $0.21(0.04 ; 0.37)$ & $0.44(0.19 ; 0.68)$ & $0.31(0.21 ; 0.41)$ \\
\hline \multicolumn{7}{|l|}{$\begin{array}{l}\text { Head of the } \\
\text { household }\end{array}$} \\
\hline Yes & $64.86(62.79 ; 66.93)$ & $65.66(64.55 ; 66.77)$ & $66.49(64.70 ; 68.27)$ & $64.18(62.70 ; 65.67)$ & $62.80(61.11 ; 64.49)$ & $64.54(63.73 ; 65.35)$ \\
\hline No & $35.14(33.07 ; 37.21)$ & $34.34(33.23 ; 35.45)$ & $33.51(31.73 ; 35.30)$ & $35.82(34.33 ; 37.30)$ & $37.20(35.51 ; 38.89)$ & $35.46(34.65 ; 36.27)$ \\
\hline \multicolumn{7}{|l|}{$\begin{array}{l}\text { Monetary gain in the } \\
\text { past } 12 \text { months }\end{array}$} \\
\hline Yes & $87.17(85.42 ; 88.92)$ & $91.16(90.16 ; 92.15)$ & $86.89(85.18 ; 88.60)$ & $84.99(83.44 ; 86.53)$ & $89.94(88.53 ; 91.35)$ & $87.65(86.83 ; 88.47)$ \\
\hline No & $9.24(7.83 ; 10.64)$ & $6.68(5.82 ; 7.54)$ & $9.83(8.52 ; 11.13)$ & $12.26(10.97 ; 13.56)$ & $8.18(6.95 ; 9.41)$ & $9.82(9.13 ; 10.51)$ \\
\hline Not informed & $3.60(2.62 ; 4.57)$ & $2.16(1.74 ; 2.58)$ & $3.29(2.16 ; 4.41)$ & $2.75(1.84 ; 3.66)$ & $1.88(1.21 ; 2.55)$ & $2.53(2.08 ; 2.99)$ \\
\hline \multicolumn{7}{|l|}{$\begin{array}{l}\text { Type of monetary } \\
\text { gain }\end{array}$} \\
\hline $\begin{array}{l}\text { Social security/ } \\
\text { Social benefit }\end{array}$ & 75.34 (72.89; 77.80) & $83.69(82.53 ; 84.86)$ & $75.89(73.60 ; 78.18)$ & $76.51(74.80 ; 78.22)$ & $82.34(80.54 ; 84.14)$ & $79.25(78.33 ; 80.18)$ \\
\hline $\begin{array}{l}\text { Employment/ } \\
\text { Patrimony }\end{array}$ & $41.68(38.79 ; 44.57)$ & $35.96(34.43 ; 37.48)$ & $38.32(35.56 ; 41.08)$ & $38.23(35.95 ; 40.51)$ & $43.41(41.09 ; 45.72)$ & $38.63(37.41 ; 39.84)$ \\
\hline $\begin{array}{l}\text { Family financial } \\
\text { support }\end{array}$ & $3.22(2.20 ; 4.24)$ & $4.10(3.54 ; 4.66)$ & $3.08(2.30 ; 3.85)$ & $4.45(3.62 ; 5.28)$ & $4.08(3.05 ; 5.11)$ & $4.15(3.70 ; 4.59)$ \\
\hline Other & $0.88(0.37 ; 1.40)$ & $1.10(0.76 ; 1.43)$ & $0.97(0.49 ; 1.46)$ & $2.09(1.46 ; 2.71)$ & $1.46(0.91 ; 2.00)$ & $1.59(1.28 ; 1.91)$ \\
\hline \multicolumn{7}{|l|}{ Health insurance } \\
\hline Yes & $17.88(14.83 ; 20.93)$ & $14.96(13.28 ; 16.64)$ & $31.96(29.05 ; 34.88)$ & $41.15(38.28 ; 44.03)$ & $35.28(32.17 ; 38.39)$ & $31.47(29.91 ; 33.04)$ \\
\hline No & $82.12(79.07 ; 85.17)$ & $85.04(83.36 ; 86.72)$ & $68.04(65.12 ; 70.95)$ & $58.85(55.97 ; 61.72)$ & $68.04(65.12 ; 70.95)$ & $68.53(66.96 ; 70.09)$ \\
\hline
\end{tabular}

95\%Cl: 95\% confidence interval.

* Asians, Indigenous, or unknown.

monthly health expenditure per capita, and proportion of monthly health expenditure per capita to monthly income per capita quintile. Families with one older adult who were not head of the household were larger on average (4.13) and had more children aged 5 years and younger when compared to families with older adults as head of the household. Area of residence and geographic region distribution were similar in the three family arrangements. 
Table 2

Types of family arrangements in Brazil. Brazilian Household Budget Survey, 2008-2009.

\begin{tabular}{lcc}
\hline Types of family arrangements & $\begin{array}{c}\text { All families } \\
\%(95 \% \mathrm{Cl})\end{array}$ & $\begin{array}{c}\text { Families with older adults } \\
\%(95 \% \mathrm{Cl})\end{array}$ \\
\hline Families without older adults & $72.39(71.69 ; 73.10)$ & - \\
Families with 1 older adult head of the household & $15.07(14.56 ; 15.59)$ & $54.59(53.28 ; 55.89)$ \\
Families with 1 older couple and head of the househol & $8.35(7.94 ; 8.76)$ & $30.25(29.03 ; 31.48)$ \\
Families with 1 older adult who was not head of the household & $4.19(3.91 ; 4.45)$ & $15.16(14.27 ; 16.05)$ \\
\hline
\end{tabular}

95\%Cl: 95\% confidence interval.

\section{Table 3}

Sociodemographic characteristics, monthly income per capita, type of monetary gain, and monthly health expenditure per capita (PPP 2009: BRL to USD) of Brazilian families with and without older adults. Brazilian Household Budget Survey, 2008-2009.

\begin{tabular}{|c|c|c|}
\hline Characteristics & $\begin{array}{l}\text { Families without older adults } \\
\qquad \%(95 \% \mathrm{Cl})\end{array}$ & $\begin{array}{l}\text { Families with older adults } \\
\qquad \%(95 \% \mathrm{Cl})\end{array}$ \\
\hline Mean number of family members ( $n$ ) & $3.42(3.39 ; 3.44)$ & $2.98(2.93 ; 3.02)$ \\
\hline \multicolumn{3}{|l|}{ Presence of children aged 5 and younger } \\
\hline Yes & $24.57(23.82 ; 25.32)$ & $7.59(6.97 ; 8.20)$ \\
\hline No & $75.43(74.68 ; 76.18)$ & $92.41(91.80 ; 93.03)$ \\
\hline \multicolumn{3}{|l|}{ Area of residence } \\
\hline Urban & $84.83(84.18 ; 85.48)$ & $83.34(82.48 ; 84.20)$ \\
\hline Rural & $15.17(14.52 ; 15.82)$ & $16.66(15.80 ; 17.52)$ \\
\hline \multicolumn{3}{|l|}{ Geographic region } \\
\hline North & $7.45(7.08 ; 7.81)$ & $5.22(4.85 ; 5.59)$ \\
\hline Northeast & $25.79(24.96 ; 26.61)$ & $26.98(25.98 ; 27.99)$ \\
\hline Central & $7.98(7.60 ; 8.36)$ & $6.50(6.12 ; 6.89)$ \\
\hline Southeast & $43.55(42.40 ; 44.70)$ & $45.51(44.13 ; 46.90)$ \\
\hline South & $15.24(14.64 ; 15.85)$ & $15.78(14.98 ; 16.58)$ \\
\hline Monthly income per capita & $745.37(715.33 ; 775.41)$ & $984.42(919.98 ; 1,048.86)$ \\
\hline \multicolumn{3}{|c|}{ Monthly income per capita by area of residence } \\
\hline Urban & $815.37(780.49 ; 850.25)$ & $1,079.92(1,003.68 ; 1,156.17)$ \\
\hline Rural & $353.82(334.61 ; 373.02)$ & $506.70(473.79 ; 539.61)$ \\
\hline \multicolumn{3}{|l|}{ Monthly income per capita by region } \\
\hline North & $512.75(467.23 ; 558.28)$ & $581.51(508.98 ; 654.03)$ \\
\hline Northeast & $438.29(410.13 ; 466.45)$ & $550.37(512.64 ; 588.10)$ \\
\hline Central & $769.90(687.17 ; 852.63)$ & $1,058.00(855.70 ; 1,260.30)$ \\
\hline Southeast & $919.53(858.87 ; 980.20)$ & $1,266.88(1,138.06 ; 1,395.70)$ \\
\hline South & $868.05(811.57 ; 924.53)$ & $1,014.89(911.91 ; 1,117.87)$ \\
\hline \multicolumn{3}{|l|}{ Monthly income per capita quintiles } \\
\hline 1 & $119.80(118.51 ; 121.09)$ & $136.36(133.57 ; 139.16)$ \\
\hline 2 & $268.06(266.69 ; 269.43)$ & $269.35(267.25 ; 271.44)$ \\
\hline 3 & $444.64(442.54 ; 446.75)$ & $443.72(440.98 ; 446.46)$ \\
\hline 4 & $742.66(737.77 ; 747.55)$ & $747.77(740.35 ; 755.18)$ \\
\hline 5 & 2,363.76 (2,253.84; 2,473.69) & $2,720.23(2,498.92 ; 2,941.53)$ \\
\hline
\end{tabular}

(continues) 
Table 3 (continued)

\section{Characteristics}

Families without older adults

$\%(95 \% \mathrm{Cl})$

Type of monetary gain

Social security/Social benefit

Employment/Patrimony

Family financial support

Others

Had a monetary health expenditure *,**

Yes

No

Monthly health expenditure per capita **

Proportion of monthly health expenditure per capita per

monthly income per capita according to income per capita quintiles ***

$\begin{array}{cc}30.52(29.76 ; 31.28) & 89.21(88.43 ; 89.99) \\ 95.84(95.56 ; 96.13) & 73.18(71.93 ; 74.44) \\ 11.01(10.53 ; 11.49) & 9.22(8.48 ; 9.97) \\ 9.61(8.91 ; 10.31) & 5.56(4.78 ; 6.35) \\ & \\ 82.29(81.59 ; 82.99) & 87.00(86.12 ; 87.88) \\ 17.71(17.01 ; 18.41) & 13.00(12.12 ; 13.88) \\ 29.77(27.98 ; 31.56) & 70.47(64.59 ; 76.34) \\ & \\ & \\ 5.20(4.95 ; 5.45) & \\ 4.41(4.16 ; 4.66) & 5.96(5.43 ; 6.49) \\ 4.00(3.79 ; 4.22) & 6.36(5.90 ; 6.82) \\ 4.07(3.85 ; 4.29) & 7.05(6.58 ; 7.51) \\ 4.04(3.82 ; 4.26) & 8.00(7.33 ; 8.68) \\ \end{array}$

Families with older adults

$\%(95 \% \mathrm{Cl})$

$\begin{array}{lll}1 & 5.20(4.95 ; 5.45) & 5.96(5.43 ; 6.49) \\ 2 & 4.41(4.16 ; 4.66) & 6.36(5.90 ; 6.82) \\ 3 & 4.00(3.79 ; 4.22) & 7.05(6.58 ; 7.51) \\ 4 & 4.07(3.85 ; 4.29) & 8.00(7.33 ; 8.68) \\ 5 & 4.04(3.82 ; 4.26) & 7.32(6.85 ; 7.79)\end{array}$

95\% Cl: 95\% confidence interval.

* Last 90 days;

** 40,683 families without older adults and 15,021 families with older adults;

$\star * * 40,619$ families without older adults and 14,985 families with older adults (100 families were excluded because they presented proportion values above 100\%).

\section{Table 4}

Sociodemographic characteristics, monthly income per capita, type of monetary gain, and monthly health expenditure per capita (PPP 2009: BRL to USD) of Brazilian families with older adults per type of family arrangement. Brazilian Household Budget Survey, 2008-2009.

\begin{tabular}{|c|c|c|c|}
\hline Characteristics & $\begin{array}{l}\text { Families with } 1 \text { older adult } \\
\text { head of the household }\end{array}$ & $\begin{array}{c}\text { Families with } 1 \text { older couple } \\
\text { head of the household }\end{array}$ & $\begin{array}{c}\text { Families with } 1 \text { older adult } \\
\text { who was not head of the } \\
\text { household }\end{array}$ \\
\hline & $\%(95 \% \mathrm{Cl})$ & $\%(95 \% \mathrm{Cl})$ & $\%(95 \% \mathrm{Cl})$ \\
\hline Mean number of family members ( $n$ ) & $2.58(2.52 ; 2.63)$ & $3.11(3.04 ; 3.18)$ & $4.13(4.01 ; 4.25)$ \\
\hline \multicolumn{4}{|l|}{ Presence of children aged 5 and younger } \\
\hline Yes & $6.11(5.45 ; 6.77)$ & $6.22(5.17 ; 7.26)$ & $15.63(13.47 ; 17.80)$ \\
\hline No & $93.89(93.23 ; 94.55)$ & $93.78(92.74 ; 94.83)$ & 84.37 (82.20; 86.53) \\
\hline \multicolumn{4}{|l|}{ Area of residence } \\
\hline Urban & $84.67(83.70 ; 85.64)$ & $80.71(79.02 ; 82.40)$ & $83.79(81.74 ; 85.85)$ \\
\hline Rural & $15.33(14.36 ; 16.30)$ & $19.29(17.60 ; 20.98)$ & $16.21(14.15 ; 18.26)$ \\
\hline \multicolumn{4}{|l|}{ Geographic region } \\
\hline North & $5.43(4.95 ; 5.90)$ & $4.48(3.90 ; 5.05)$ & $5.96(5.02 ; 6.89)$ \\
\hline Northeast & $27.83(26.53 ; 29.13)$ & $25.75(23.97 ; 27.53)$ & $26.39(24.00 ; 28.78)$ \\
\hline Central & $6.97(6.42 ; 7.52)$ & $5.65(5.02 ; 6.28)$ & $6.53(5.60 ; 7.46)$ \\
\hline Southeast & $44.77(42.96 ; 46.57)$ & $47.69(45.17 ; 50.20)$ & $43.87(40.40 ; 47.34)$ \\
\hline South & $15.01(13.94 ; 16.08)$ & $16.44(14.90 ; 17.97)$ & $17.24(15.08 ; 19.41)$ \\
\hline
\end{tabular}

(continues) 
Table 4 (continued)

\begin{tabular}{|c|c|c|c|}
\hline Characteristics & $\begin{array}{l}\text { Families with } 1 \text { older adult } \\
\text { head of the household }\end{array}$ & $\begin{array}{l}\text { Families with } 1 \text { older couple } \\
\text { head of the household }\end{array}$ & $\begin{array}{l}\text { Families with } 1 \text { older adult } \\
\text { who was not head of the } \\
\text { household }\end{array}$ \\
\hline & $\%(95 \% \mathrm{Cl})$ & $\%(95 \% \mathrm{Cl})$ & \\
\hline Monthly income per capita & $1,057.94(957.87 ; 1,158.01)$ & $974.64(886.84 ; 1,062.44)$ & $739.19(648.42 ; 829.95)$ \\
\hline \multicolumn{4}{|l|}{$\begin{array}{l}\text { Monthly income per capita by area of } \\
\text { residence }\end{array}$} \\
\hline Urban & $1,157.84(1,040.87 ; 1,274.82)$ & $1,081.04(974.69 ; 1,187.39)$ & 794.26 (687.72; 900.79) \\
\hline Rural & $506.11(465.82 ; 546.40)$ & $529.52(468.30 ; 590.74)$ & $454.49(371.57 ; 537.42)$ \\
\hline \multicolumn{4}{|l|}{ Monthly income per capita by region } \\
\hline North & $566.64(509.59 ; 623.69)$ & $622.54(443.35 ; 801.72)$ & $568.77(432.08 ; 705.46)$ \\
\hline Northeast & $552.16(507.07 ; 597.25)$ & $569.23(505.71 ; 632.76)$ & $506.84(423.44 ; 590.23)$ \\
\hline Central & 1,127.56 (891.41; 1,363.72) & 1,134.96 (808.93; 1,460.99) & $658.00(556.35 ; 759.64)$ \\
\hline Southeast & $1,393.73(1,189.56 ; 1,597.90)$ & $1,213.95(1,046.03 ; 1,381.86)$ & $915.65(721.42 ; 1,109.88)$ \\
\hline South & 1,139.56 (941.73; 1,337.40) & $956.31(843.49 ; 1,069.14)$ & 735.52 (649.76; 821.28) \\
\hline \multicolumn{4}{|l|}{ Monthly income per capita quintiles } \\
\hline 1 & $134.71(131.14 ; 138.27)$ & $146.71(142.58 ; 150.84)$ & $132.12(125.08 ; 139.16)$ \\
\hline 2 & $268.06(264.97 ; 271.15)$ & $274.60(271.15 ; 278.05)$ & $264.10(259.49 ; 268.72)$ \\
\hline 3 & $443.40(439.68 ; 447.12)$ & $443.13(438.40 ; 447.86)$ & $446.54(439.04 ; 454.03)$ \\
\hline 4 & 750.67 (741.30; 760.04) & $742.64(728.18 ; 757.10)$ & 747.02 (728.82; 765.22) \\
\hline 5 & $2,868.42(2,527.98 ; 3,208.87)$ & $2,649.92(2,358.88 ; 2,940.96)$ & $2,179.09(1,772.54 ; 2,585.65)$ \\
\hline \multicolumn{4}{|l|}{ Type of monetary gain } \\
\hline Social security/Social benefit & $87.29(86.11 ; 88.47)$ & $94.48(93.34 ; 95.61)$ & $85.61(83.48 ; 87.74)$ \\
\hline Employment/Patrimony & $70.07(68.37 ; 71.77)$ & $70.04(67.70 ; 72.38)$ & $90.67(88.81 ; 92.53)$ \\
\hline Family financial support & $9.29(8.37 ; 10.21)$ & $9.32(7.87 ; 10.76)$ & $8.81(7.04 ; 10.59)$ \\
\hline Others & $4.96(4.13 ; 5.79)$ & $5.32(3.96 ; 6.67)$ & $8.23(6.11 ; 10.35)$ \\
\hline \multicolumn{4}{|l|}{ Had a monetary health expenditure $*, \star *$} \\
\hline Yes & $84.24(83.06 ; 85.41)$ & $90.02(88.53 ; 91.51)$ & $90.85(89.02 ; 92.68)$ \\
\hline No & $15.76(14.59 ; 16.94)$ & $9.98(8.49 ; 11.47)$ & $9.15(7.32 ; 10.98)$ \\
\hline Monthly health expenditure per capita ** & $72.99(64.10 ; 81.88)$ & $76.11(68.57 ; 83.66)$ & $50.24(41.23 ; 59.25)$ \\
\hline \multicolumn{4}{|l|}{$\begin{array}{l}\text { Proportion of monthly health expenditure } \\
\text { per capita per monthly income per capita } \\
\text { according to income per capita quintiles } * * *\end{array}$} \\
\hline 1 & $5.22(4.60 ; 5.85)$ & $7.63(5.97 ; 9.29)$ & $6.45(5.41 ; 7.49)$ \\
\hline 2 & $5.90(5.30 ; 6.50)$ & $7.25(6.47 ; 8.03)$ & $6.07(4.79 ; 7.35)$ \\
\hline 3 & $6.21(5.71 ; 6.70)$ & $7.87(7.07 ; 8.68)$ & $8.14(6.43 ; 9.85)$ \\
\hline 4 & $7.56(6.56 ; 8.57)$ & $9.18(8.07 ; 10.29)$ & $7.22(6.17 ; 8.27)$ \\
\hline 5 & $7.13(6.47 ; 7.78)$ & $7.93(7.19 ; 8.68)$ & $6.69(5.59 ; 7.79)$ \\
\hline
\end{tabular}

95\%Cl: 95\% confidence interval.

* Last 90 days;

** 40,683 families without older adults and 15,021 families with older adults;

$\star \star \star 40,619$ families without older adults and 14,985 families with older adults ( 100 families were excluded because they presented proportion values above 100\%).

Average monthly income per capita was significantly higher in families with one older adult and with an older couple with one head of the household when compared to families with one older adult who was not head of the household. Monthly income per capita in urban areas was significantly higher than in rural areas in all living arrangements and families with an older adult who was not head of the household had the lowest income in both areas. Geographic region distribution presented significant differences with higher income in the Central, Southeast, and South, and lower in the North and Northeast for the three living arrangements. The average monthly income per capita quintile 
differed only for the highest quintile, with a lower value for families with one older adult who was not head of the household.

Families with an older couple reported more often earnings from social security (94\%) when compared to the other types of living arrangements. Families with one older adult who was not head of the household often reported monetary gains from employment/patrimony (90\%).

Families with one older adult head of the household and families with one older couple and head of the household had similar monthly per capita health expenditure, significantly higher than families with one older adult who was not head of the household. Families with one older couple and head of the household had the highest proportions of monthly health expenditure per capita per monthly income per capita quintile, but without significant statistical difference. The lowest income quintile in all family arrangements had the lowest proportion of health expenditure, but there was no consistent tendency of increasing proportions with higher income.

\section{Discussion}

To the best of our knowledge this is the first national study in Brazil that investigated income and health expenditure of families with older adults in different living arrangements. We showed that comparing information on individual older adults, families with and without older adults, and living arrangements in families with older adults increases our understanding of the relationship complexities between income and health expenditure for older adults.

The different living arrangements analysis of families with older adults allowed us to detect differences in family profiles regarding the economic role of the older adult within the family, as head or not of the household. Most older adults were head of the household (85\%). However, even in those households in which older adults were not the head of the household, around $85 \%$ received some monetary gain from social security/social policy.

Families with on older adult head of the household were smaller, had less children under 5 years old, with $30 \%$ of them living alone. Families with an older adults' couple also had few children under 5 years old and were similar to families with one older adult but had a lower income per capita. Families with an older adult who was not head of the household were larger, had almost three times more children under 5 years old, and had the lowest income.

Despite the average monthly income per capita being higher in families with an older adult head of the household, the income distribution quintile in the living arrangements differed only for the highest quintile. The distributive effect of social policies seems to protect families up to a certain level of income.

Family arrangements with older adults had a higher frequency and monetary health expenditure value than families without them. Families with an older adult who was head of the household and with one older couple had higher monthly health expenditure per capita when compared to families with one older adult who was not head of the household. However, the proportions of health expenditure in income level quintile did not vary much and had no consistent tendency.

For older adults, being able to afford health expenditure when judged necessary is important, but the ability or not to afford health expenditure depends on other essential expenses and types of health services used. In this study, older adults paid for private health care more often in regions with better socioeconomic conditions, even though the household proportions of health expenditure per capita in the income per capita per income quintile do not differ as much and are lower than other contexts 27 .

There are very few studies in the literature about living arrangements and older adults in Brazil and Latin America. Studies in the United States and Asian countries, with no public health systems and no social policies for poor older adults, indicate an important increase in health expenditure in families with older adults $28,29,30,31$. The health spending values in families with older people vary enormously in the literature and are influenced by the country of residence, income, level of education, gender, medical infrastructure, number and type of morbidities, among others aspects 32,33,34.

In a study conducted in China, catastrophic health expenditure incidence and intensity were relatively high among older people's households with chronic disease patients ${ }^{30}$. The main associ- 
ated factors of catastrophic health expenditure include: household size, having members $>65$ years, having members with $\geq 2$ chronic diseases, per capita income, and older people's household members showing healthcare-seeking behaviors 30 . Disproportionate catastrophic health expenditure concentration was noted among older people's households and poor older people's households showed a higher probability of experiencing such expenditure ${ }^{30}$. It is important to highlight that the methods to estimate health out-of-pocket expenditures, concept adopted in this study, are different than those for measuring catastrophic out-of-pocket health care expenditures.

A study in India investigated trends in out-of-pocket health care payments and catastrophic health expenditure by household age composition. Surveys conducted between 1993 and 2014 were analyzed. Mean per capita out-of-pocket payments by households with older people only were higher than those of all other households, including households with older people, but no children. Data about household income and financial sources were not available 31 .

On the other hand, older adults' presence is not always associated with higher healthcare expenditures. Determinants of catastrophic health expenditure in Nigeria were investigated using data from the 2009/2010 Harmonized Nigeria Living Standard Survey 34 . Household and individual characteristics associated with catastrophic health expenditure were determined using regression models. Having a member $>65$ years was not significantly associated with catastrophic health expenditure, but the possible causes associated with this finding were not mentioned 34 .

This study has limitations that must be acknowledged. Household surveys, traditionally designed to measure income distribution, usually underestimate higher monetary gains due to sampling, questionnaire structure/design, or by non-response or lack of participants' knowledge about their exact earnings. Government data from the Brazilian Federal Revenue on personal income tax declarations showed a wealth concentration level larger than other sources, including the POF 35 . Another potential limitation is the restrictive period of when health expenditure was measured. By considering only the last 30 days for drugs and 90 days for other health expenditure, there is a risk of under or overestimating such expenditures.

Positive aspects of this study include a partnership between IBGE and the Brazilian Ministry of Health to conduct the POF 2008-2009, which provided financial resources and technical support in research and data analysis regarding health expenses and presented strict quality control at all research stages. The POF 2008-2009 was conducted at the urban and rural areas, has national coverage, and the family was considered the analysis unit, which allows a better understanding of the influence of the family situation on older adults' life condition characteristics.

Furthermore, it is the first nationwide household survey to divide the pensions of civil servants from the pensions of the Social Security General Scheme, which are paid by the National Institute of Social Security (INSS in Portuguese). This also allows to highlight the transfers made by the Brazilian Income Transfer Program and by other financial sources.

\section{Conclusion}

This study contributes to further understand the social vulnerability situation of older Brazilian adults and their families by bringing new insights to this research area. There seems to be positive impacts of the social security policies expanded from 2000 onwards on the household income level and health expenditure of families with an older adult, especially those with lower income levels.

The BPC is, along with rural retirement, one of the points of the government's pension reform proposal (Constitutional Amendment 6/2019) 19 that faced greater resistance. Currently, a monthly minimum wage (BRL 998.00) is paid to disabled people and older people aged 65 and over who prove not to have the means to support themselves and do not have family support. This pension has been maintained by the Legislative until now but showing its importance for the older adults population continues to be essential.

Data from the most recent POF survey and comparison with our results will be able to provide insights into the effects of the years of economic crisis and political instability on income and health expenditure in families with older adults. 
To broaden the understanding on the subject, new questions may be answered with other sources or/with the POF study, for example: How does changing economic status affect health spending in families with older people, whether the access to pharmaceutical care policies influences the reduction of health inequalities, whether the health spending results in health gains for older people, and which morbidities are most associated with health expenditure.

These answers would help assess whether and how some financial protection or health initiatives can be created or changed. A more detailed study of health expenditure and its relationship with other needs is also necessary, and a focus on families rather than individuals contributes to a better understanding of the elements involved in these decisions.

\section{Contributors}

C. G. Faustino and H. M. D. Novaes contributed to the study design, data analysis and interpretation, article writing and critical review; and approved the final version. R. B. Levy, D. S. Canella, and C. De Oliveira contributed to the study design and data analysis and interpretation.

\section{Additional informations}

ORCID: Christine Grutzmann Faustino (00000003-1660-5517); Renata Bertazzi Levy (00000001-5388-7002); Daniela Silva Canella (00000001-9672-4983); César De Oliveira (0000-00024099-4762); Hillegonda Maria Dutilh Novaes (0000-0001-9849-0324).

\section{Acknowledgments}

C. G. Faustino received a doctoral scholarship from the Brazilian Graduate Studies Coordinating Board (Capes) and Science Without Borders Program (process 201371/2015-4).

\section{References}

1. World Health Organization. World report on ageing and health. http://apps.who.int/iris/ bitstream/10665/186463/1/9789240694811_ eng.pdf (accessed on Jun/2018).

2. Instituto Brasileiro de Geografia e Estatística. Projeções da população do Brasil e Unidades da Federação por sexo e idade: 2010-2060. https:// www.ibge.gov.br/estatisticas/sociais/popula cao/9109-projecao-da-populacao.html? =\&t= resultados (accessed on 08/Jun/2019).

3. Chatterji S, Byles J, Cutler D, Seeman T, Verdes E. Health, functioning, and disability in older adults: present status and future implications. Lancet 2015; 385:563-75.

4. Camarano AA, Pasinato MT. O envelhecimento populacional na agenda das políticas públicas. In: Camarano AA, organizadora. Os novos idosos brasileiros muito além dos 60? Rio de Janeiro: Instituto de Pesquisa Econômica Aplicada; 2004. p. 253-92.

5. Weissman JD, Russell D. Relationships between living arrangements and health status among older adults in the United States, 20092014: findings from the National Health Interview Survey. J Appl Gerontol 2018; 37:7-25.

6. Yusuf F, Leeder SR. Can't escape it: the out-ofpocket cost of health care in Australia. Med J Aust 2013; 199:475-8.

7. Instituto Brasileiro de Geografia e Estatística. Pesquisa de Orçamentos Familiares: 20082009. Despesas, rendimentos e condições de vida. Rio de Janeiro: Instituto Brasileiro de Geografia e Estatística; 2010.

8. Wiemers EE, Slanchev V, McGarry K, Hotz VJ. Living arrangements of mothers and their adult children over the life course. Res Aging 2017; 39:111-34.

9. Marengoni A, Angleman S, Melis R, Mangialasche F, Karp A, Garmen A, et al. Aging with multimorbidity: a systematic review of the literature. Ageing Res Rev 2011; 10:430-9.

10. Alam K, Mahal A. Economic impacts of health shocks on households in low and middle income countries: a review of the literature. Global Health 2014; 10:21. 
11. Teerawichitchainan B, Pothisiri W, Long GT How do living arrangements and intergenerational support matter for psychological health of elderly parents? Evidence from Myanmar, Vietnam, and Thailand. Soc Sci Med 2015; 136-7:106-16.

12. Norton EC, Stearns SC. Health care expenditures. In: Uhlenberg P, editor. International handbook of population aging. Dordrecht: Springer; 2009. p. 631-45.

13. Instituto Brasileiro de Geografia e Estatística. Panorama nacional e internacional da produção de indicadores sociais. Rio de Janeiro: Instituto Brasileiro de Geografia e Estatística; 2016.

14. Ocké-Reis CO, Silveira FG, Andreazzi MFS. Avaliação dos gastos das famílias com a assistência médica no Brasil: o caso dos planos de saúde. Rio de Janeiro: Instituto de Pesquisa Econômica Aplicada; 2002. (Texto para Discussão, 0921).

15. Silveira FG, Osório RG, Piola SF. Os gastos das famílias com saúde. Ciênc Saúde Colet 2002; 7:719-31.

16. Diniz BPC, Servo LMS, Piola SF, Eirado M. Gasto das famílias com saúde no Brasil: evolução e debate sobre gasto catastrófico. In: Silveira FG, Servo LMS, Menezes T, Piola SF, organizadores. Gasto e consumo das famílias brasileiras contemporâneas. v. 2. Brasília: Instituto de Pesquisa Econômica Aplicada; 2007. p. 143-66.

17. Viacava F, Oliveira RAD, Carvalho CC, Laguardia J, Bellido JG. SUS: oferta, acesso e utilização de serviços de saúde nos últimos 30 anos. Ciênc Saúde Colet 2018; 23:1751-62.

18. Instituto Brasileiro de Geografia e Estatística. IBGE inicia a Pesquisa de Orçamentos Familiares (POF) 2017/2018. Agência IBGE de Notícias 2017; 26 jun. https://agenciadenoti cias.ibge.gov.br/agencia-sala-de-imprensa/ 2013-agencia-de-noticias/releases/10448ibge-inicia-a-pesquisa-de-orcamentos-fami liares-pof-2017-2018.

19. Baptista R. BPC é um dos pontos polêmicos da reforma da Previdência. Senado Notícias 2019; 9 mai. https://www12.senado.leg.br/noticias/ materias/2019/05/09/bpc-e-um-dos-pontos -polemicos-da-reforma-da-previdencia.

20. Instituto Brasileiro de Geografia e Estatística. Pesquisa de Orçamentos Familiares 20082009. Manual do agente de pesquisa. Rio de Janeiro: Instituto Brasileiro de Geografia e Estatística; 2008.

21. Ministério do Desenvolvimento Social. Ações e programas. http://www.mds.gov.br/ (accessed on Apr/2017).

22. Ministério do Trabalho e Previdência Social. Classificação de benefícios concedidos pelo Regime Geral da Previdência Social do Ministério da Previdência Social. 2015. http://www. mtps.gov.br/dados-abertos/dados-da-previ dencia/previdencia-social-e-inss/anuario-es tatistico-da-previdencia-social-aeps (accessed on Aug/2017)
23. The World Bank. PPP conversion factor, GDP (LCU per international \$). http://data.world bank.org/indicator/PA.NUS.PPP (accessed on $\mathrm{Feb} / 2019$ ).

24. United Nations. Principles and recommendations for population and 1 housing censuses revision 3. New York: United Nations; 2015. (Statistical Papers. Series M, n. 67/rev. 3).

25. Alcântara A. Envelhecer no contexto rural: a vida depois do aposento. In: Alcântara $\mathrm{AO}$, Camarano AA, Giacomin KC, organizadores. Política nacional do idoso: velhas e novas questões. Rio de Janeiro: Instituto de Pesquisa Econômica Aplicada; 2016. p. 323-42.

26. Resende GM, Cruz BO, Monteiro Neto A, Castro CN, Barufi AMB, Coelho MHP, et al. Fatos recentes do desenvolvimento regional no Brasil. In: Resende GM, organizador. Avaliação de políticas públicas no Brasil: uma análise de seus impactos regionais. v. 1. Rio de Janeiro: Instituto de Pesquisa Econômica Aplicada; 2014. p. 25-90.

27. Boing AC, Bertoldi AD, Barros AJD, Posenato LG, Peres KG. Socioeconomic inequality in catastrophic health expenditure in Brazil. Rev Saúde Pública 2014; 48:632-41.

28. Baird K. High out-of-pocket medical spending among the poor and elderly in nine developed countries. Health Serv Res 2016; 51:1467-88.

29. Picco L, Achilla E, Abdin E, Chong SA, Vaingankar JA, McCrone P, et al. Economic burden of multimorbidity among older adults: impact on healthcare and societal costs. BMC Health Serv Res 2016; 16:173.

30. Wang Z, Li X, Chen M. Catastrophic health expenditures and its inequality in elderly households with chronic disease patients in China. Int J Equity Health 2015; 14:8.

31. Pandey A, Ploubidis GB, Clarke L, Dandona L. Trends in catastrophic health expenditure in India: 1993 to 2014. Bull World Health Organ 2018; 96:18-28.

32. Corrieri S, Heider D, Matschinger H, Lehnert T, Raum E, König HH. Income-, educationand gender-related inequalities in out-ofpocket health-care payments for $65+$ patients - a systematic review. Int J Equity Health 2010; 9:20.

33. Islam MM, Yen L, Valderas JM, McRae IS. Out-of-pocket expenditure by Australian seniors with chronic disease: the effect of specific diseases and morbidity clusters. BMC Public Health 2014; 14:1008.

34. Aregbeshola BS, Khan SM. Determinants of catastrophic health expenditure in Nigeria. Eur J Health Econ 2018; 19:521-32.

35. Medeiros M, Souza PHGF, Castro FA. O topo da distribuição de renda no Brasil: primeiras estimativas com dados tributários e comparação com pesquisas domiciliares (2006-2012). Dados 2015; 58:7-36. 


\section{Resumo}

O estudo teve como principal objetivo caracterizar os padrões domiciliares sociodemográficos e econômicos em diferentes arranjos de moradia em famílias com idosos no Brasil e a associação com renda e gastos diretos em saúde. Os dados foram extraídos da base de dados da Pesquisa de Orçamentos Familiares (POF) de 2008/2009 do Instituto Brasileiro de Geografia e Estatística. As famílias com idosos representavam 28\% do total, eram menores e tinha uma média de renda mais elevada, comparado a famílias sem idosos. Os adultos idosos eram chefes de família em $85 \%$ do total, $e$ com renda originária principalmente das politicas de proteção social. As famílias chefiadas por um adulto ou casal idoso tinham média de renda mensal mais elevada. A proporção de gastos diretos em saúde de acordo com o quintil de renda per capita era mais alta em famílias chefiadas com um adulto ou casal idoso, comparado a famílias com um idoso não chefe de domicílio, e mais ainda em famílias sem idosos. Os achados permitem a identificação de impactos positivos potenciais sobre a qualidade de vida de famílias com idosos no Brasil. A renda domiciliar mais alta das famílias com idosos é consequência da expansão das políticas inclusivas de políticas de proteção social para idosos no Brasil nos anos 2000, especialmente para famílias com renda mais baixa, que representam $80 \%$ dessa população. É provável que a crise econômica e política dos anos 2010 tenha reduzido a vantagem relativa dessas famílias, e o estudo atual permitirá comparações com os resultados da próxima POF.

Idoso; Família; Renda; Gastos em Saúde;

Previdência Social

\section{Resumen}

El objetivo principal de este estudio fue caracterizar los patrones sociodemográficos y económicos de los hogares en los que conviven familias con ancianos en Brasil, y su relación con los ingresos $y$ gastos personales en salud. Los datos se extrajeron de la base de datos de la Encuesta de Presupuestos Familiares (POF, por sus siglas en portugués) en 2008-2009 del Instituto Brasileño de Geografía y Estadística. Las familias con ancianos representaron un $28 \%$ de todas las familias, eran pequeñas $y$ contaban con ingresos promedio altos, cuando se compararon con las familias sin ancianos en el hogar. Los ancianos eran los cabeza de familia en un $85 \%$ de las familias, con ingresos basados principalmente en politicas de protección social. Las familias con ancianos o parejas de ancianos cabezas del hogar contaban con un promedio de ingresos significativamente más alto. La proporción de gasto personal en salud por quintil de ingresos per cápita fue mayor en las familias con una pareja o un anciano como cabeza de familia, cuando se comparó con las familias sin ancianos cabeza de familia, e incluso mayor respecto a las familias sin ancianos en el hogar. Estos resultados permitieron la identificación de potenciales impactos positivos en la calidad de vida de las familias con ancianos en Brasil. Los ingresos más altos por hogar de familias con ancianos son una consecuencia de la expansión de la protección social inclusiva en Brasil durante la primera década del 2000, especialmente para familias con niveles promedio más bajos de ingresos, representando un 4/5 de esta población. La crisis política y económica a partir del año 2010 ha reducido probablemente la ventaja relativa de estas familias, lo que permitirá comparaciones entre este estudio y los resultados de posteriores.

Anciano; Familia; Renta; Gastos en Salud; Seguridad Social
Submitted on 09/Mar/2019

Final version resubmitted on 05/Aug/2019 Approved on 16/Sep/2019 